\title{
Erratum to: An accurate DNA marker assay for stem rust resistance gene $S r 2$ in wheat
}

\author{
R. Mago $\cdot$ H. Simkova $\cdot$ G. Brown-Guedira $\cdot$ S. Dreisigacker $\cdot$ \\ J. Breen - Y. Jin · R. Singh • R. Appels • E. S. Lagudah • \\ J. Ellis $\cdot$ J. Dolezel $\cdot$ W. Spielmeyer
}

Published online: 24 December 2010

(C) Springer-Verlag 2010

\section{Erratum to: Theor Appl Genet \\ DOI 10.1007/s00122-010-1482-7}

In the original version of the article, co-authors H. Simkova and J. Dolezel were unfortunately not listed.

The online version of the original article can be found under doi:10.1007/s00122-010-1482-7.

R. Mago · E. S. Lagudah · J. Ellis · W. Spielmeyer $(\square)$

CSIRO Plant Industry, GPO Box 1600,

Canberra 2601, Australia

e-mail: wolfgang.spielmeyer@csiro.au

J. Breen · R. Appels

Centre for Comparative Genomics, Murdoch University,

Perth, WA 6150, Australia

S. Dreisigacker $\cdot$ R. Singh

CIMMYT Apdo, Postal 6-641, 06600 Mexico, D.F., Mexico

G. Brown-Guedira

USDA-ARS Eastern Regional Genotyping Laboratory,

North Carolina State University, Raleigh,

NC 27695-7620, USA

Y. Jin

USDA-ARS Cereal Disease Lab, University of Minnesota,

Saint Paul, MN 55108, USA

H. Simkova $\cdot$ J. Dolezel

Laboratory of Molecular Cytogenetics and Cytometry,

Institute of Experimental Botany, Sokolovska 6,

77200 Olomouc, Czech Republic 